pag

Business School

WORKING PAPER SERIES

\begin{tabular}{c|l} 
Working Paper & $\begin{array}{l}\text { Efficiency of e-Learning: the case of } \\
\text { French Bank Sales Force }\end{array}$ \\
$2014-354$ & $\begin{array}{l}\text { Erick LEROUX } \\
\text { Jean-Michel SAHUT }\end{array}$
\end{tabular}

http://www.ipag.fr/fr/accueil/la-recherche/publications-WP.html

IPAG Business School

184, Boulevard Saint-Germain

75006 Paris

France

IPAG working papers are circulated for discussion and comments only. They have not been peer-reviewed and may not be reproduced without permission of the authors. 


\title{
Efficiency of e-Learning: the case of French Bank Sales Force
}

\author{
Erick LEROUX \\ Associate Professor, IUT de Saint Denis, LARGEPA Paris II \\ Jean-Michel SAHUT \\ HEG Geneva - University of Applied Sciences
}

\begin{abstract}
This article investigates the use and the satisfaction derived from e-learning training by sales representatives of commercial banks in France.

The research carried out among these representatives concerns a banking training scheme which was followed from work or from home. The analysis of the data gathered from about thirty interviews shows that learners were satisfied with this e-learning even if it was regularly checked by their superiors. They particularly appreciated the flexibility and the interactivity of e-learning which allowed them to develop new banking skills and to be more autonomous in their commercial function.
\end{abstract}

Keywords: eLearning, continuous training, sales force, commercial bank, textual analysis

JEL Classification: M53, O33, L86 
The last few years have seen a rapid expansion in distance learning courses offered to employees. Using Internet, Intranet or magnetic media (hereafter referred to as e-learning), this training has twin objectives: skill acquisition through an individualized course and reduced training costs (Kalika, 2000). These two advantages of e-learning are specifically highlighted by software engineering firms which offer complete standard training courses which can be followed with a minimum of assistance, such as office automation courses. Thus, e-learning offers the right training course, at a convenient time, for all (to suit their level and preferred way of learning) and seems to be one of the best solutions to overcome cost constraints. It is therefore possible to study from ones work station, with complete autonomy, and to progress at one's own pace. However, this freedom soon comes up against the hard reality of the professional environment. The employee, whether he has had the training suggested by his superior or has himself made the request, often finds himself left to his own devices and must constantly juggle between his training and his work. This situation is especially pertinent for sales staff who must divide their time between negotiations directly with customers or potential customers; doing all their paperwork and following their chosen training course. In France, the human resources management of several banking networks have decided to adopt a policy of e-learning to enable their sales staff to improve their knowledge in various banking fields such as banking regulations, financial markets, and asset management. However, the results appear mixed even within the same organisation. On an academic level, most research has dealt with the description, advantages and methods of elearning. Little research has focussed on the acceptance of e-learning and more practically on the success factors. This research aims therefore to better understand the success factors of an e-learning course, taking into account the specific temporal constraints of sales staff, their expectations and the fact that they may not be totally adept at using information and communication technology.

This article is organized as follows. In the first part, we define the concept of e-learning, its role in training and its advantages. In the second part, we reveal the results of a study carried out on bank sales staff using a textual analysis of the semi-structured interviews we conducted. In particular, we discuss the sales staff's perception of their e-learning banking course as well as the monitoring role of the human resources management.

\section{I/ E-learning: concept, advantages, disadvantages and risks}

In this part, we start by defining the concept of e-learning and then we look at e-learning as a learning process. Lastly, we discuss the advantages and the limitations of this training method, and the risk of the student abandoning the course.

\subsection{Conceptual framework, definition and concepts}

According to Kaplan-Leiserson (2000), "e-learning is a training process by which individuals acquire new skills or knowledge thanks to information and communication technologies (hereafter ICT)". E-learning or training using new technology makes distance training possible. Broadly speaking distance training is characterized by a separation of the acts of teaching and learning; a modular approach to teaching; a quasi-industrial production of educational material and the isolation of the learner. Distance training already existed before ICT but the latter has taken it to another level. Several theorists and practioners have tried to clarify the concept of e-learning by highlighting its main features. Keegan (1994), for example, identifies six main elements:

- the geographical distance between the teacher and the learner. Contrary to traditional faceto-face teaching (F2F), in which the method of knowledge transfer depends on the capacity of 
the teacher to teach the lessons, distance training relies mainly on putting the learner in touch with the information through pre-prepared situations,

- the fact that the training organisation guarantees the quality of the teaching material $/ \mathrm{method}$ (a team of content developers conceive the training situations) whereas in traditional teaching, it is the teacher who carries out the teaching activity in front of the learners,

- a blended learning approach using different media. The training uses communication devices since the totality of the course work can only be transmitted to the learner by ICT even when the communication between learner and teacher is in real time.

- bidirectional communication is an essential characteristic of distance training. Distance training should not be perceived as only a tool for sending documents as it gives learners access to tutors (facilitators), who they can contact directly,

- the possibility of organizing remote meetings (virtual classroom). This enables learners on the same course to meet and discuss specific areas of the coursework,

- the integration of this practice in a system of industrial production. E-learning is a product whose educational material must be created, marketed and distributed.

For the student e-learning is a vector of change. It provides a different learning experience by acquiring various levels of skills autonomously.

\subsection{E-learning and training}

E-learning offers the student a personalized learning programme, but this method of training requires him, beforehand, to possess certain skills.

\subsubsection{E-learning, individualized training}

ICT has allowed learners to be more autonomous by choosing individualized training courses corresponding to their expectations in terms of content and training method. E-learning is not so much a demand-based as an offer-based system, which allows all learners to follow the training programme whatever their level, and to use the teaching aid and the method that they prefer. It is very flexible because of its modular approach. In practical terms by using Internet or Intranet networks, e-learning can be:

- synchronous: the training is carried out in real-time and can take several forms depending on the degree of interaction with the teacher and the other learners such as a lesson by videoconference; a virtual class created through a learning management system (LMS); an online chat with the teacher, etc

- asynchronous with discussion forums or a learning management system which allows teachers or tutors to follow the students work through email (Zornada, 2005). The learner progresses at his own pace working on modules which give him access to different stages of the course, demonstrations, exercises and external resources (links to Web pages or files to be downloaded).

Ultimately, e-learning is based on an individualized training method. It is also a method of skill acquisition integrated in the human resource development strategy using electronic media to connect to a tutor via a training centre. Although the tool is attractive, minimal skills are still required to be able to follow an e-learning course.

\subsubsection{Pre-requisite skills and acquired skills}

Even if e-learning allows the learner to acquire skills, he must already possess certain skills to be able to benefit fully (Looney, 2009). To be able to participate in an e-learning session requires confident use of multi-media and Internet tools as well as good writing skills, which is a precondition to the use of any new training method (Davis et al., 1989). E-learning allows 
the learner more time to make remarks or ask questions compared to the F2F model. Consequently, he can think in greater depth about the course content to identify eventual difficulties which he may encounter. When the learner is in discussion with the tutor, he makes more effort to explain his problems because the tutor will have to understand him immediately, if it wants a clear answer. In addition, the means of communication encourages the learner to re-read his notes and better prepare what he wants to ask the tutor. In the case of discussion forums, when he discusses with other learners, the student has to formalize his remarks well in order to interest the other learners and to provoke a reaction. In other words, the relevance and the clarity of the message will encourage (or not) the other learners to answer or start a debate. Certain training courses require the learner to keep to a learning strategy which is imposed by the program. This is subsequently monitored to check that the work has been carried out and matches the set objectives. However, other training courses, like those for language learning, offer the learner the possibility to follow a nonlinear progression. In other words, he can choose between modules which focus on dialogue, grammar or vocabulary.

\subsection{Advantages, disadvantages and risks for the company}

Banks attach great importance to training members of their sales force because to a large extent the success of the sales policy depends on them. In addition to the contents of the training, the method of skills acquisition it is just as important. The type of training course chosen ( $\mathrm{F} 2 \mathrm{~F}$ or remote) depends on the perceived advantages but also on the limitations, and in particular on the risk of the learners abandoning the course.

\subsubsection{Advantages and limitations for the company}

The most frequently quoted argument in favour of e-learning is primarily the reduced cost compared to $\mathrm{F} 2 \mathrm{~F}$ training ${ }^{1}$.. Indeed, e-learning enables a reduction of:

- costs associated with the training, such as travelling expenses and accommodation,

- costs linked to the learner's availability thanks to the optimization of time management,

- overall costs of the training by choosing self-study or online training for the employee in order to concentrate the trainer's contribution in areas with greater added value (sharing experiences, examples from real life situations...).

By dematerializing the training space, ${ }^{2}$ e-learning can be made cost-effective by making the elearning applications available on learning management systems which can be used by a large number of learners. It thus gives a better return on investment for training schemes and ensures that the content of the training courses and the message transmitted are identical whatever the country.

\subsubsection{Limits of e-learning and the risks of abandonment}

Although e-learning provides the firm with numerous advantages compared to a traditional F2F course, the limitations of this innovating method of training should be considered. The principal limitations of e-learning are the following:

- solitary learning is not appropriate for all learners. Asking questions by e-mail or Internet discussion forums is an imperfect solution to the need for interaction and the exchange of ideas and viewpoints,

\footnotetext{
${ }^{1}$ http://www.llmagazine.com/e_learn/resources/pdfs/ROI_training.pdf

2 For international companies, e-learning facilitates the training of employees working on different sites around the world.
} 
- the learner has difficulty studying continually for more than an hour,

- the effort required to study by e-learning is greater than for traditional study methods. The learner cannot be passive: $\mathrm{He}$ is the main player in his training. Some learners risk falling into 'surfing' mode.

- Technical constraints: - each connection constitutes a potential problem.

Added to that is the risk of the learner abandoning the training.

Studies show a drop out rate of approximately $30 \%$ for students in Britain and America (MSJC Research Office, 2004). This rate remains difficult to measure because its definition is prone to interpretation and the organizations are reluctant to communicate on this topic. With adult learners, one can suppose that this rate is lower because, by definition, they are more responsible. Nevertheless, they need to find the necessary resources (time in particular) to take part in a training activity and to progress, which undeniable seems difficult for some. Also, it is legitimate to question how well the e-learning courses intended for bank sales advisors achieve the goals set by the firm and the learners.

On a theoretical level, several authors have tried to explain the drop out rate for learners. In particular, Kember (1990) offered an explanatory model by first asking himself what the difference was between students who blamed their failure on not being able to reconcile their studies with the other constraints in their life, and those who, even with the same constraints, made a success of their studies. This model takes into account the capacity of the learner to integrate all the components related to his situation knowing that each one influences the others. Thus, Kember's model includes the following components:

- the commitment and motivation to follow the training,

- the characteristics of the learner: type, age, civil status, number of children,

- social elements related to work, pedagogical approach (media used) and to the style of training,

- various aspects such as costs related to the training and its duration, and the learner's expectations about the benefits of the training.

\section{Empirical validation, main results and discussion}

This research work uses an abductive approach. The aim of the exploratory study presented below is to better understand the conditions for success of e-learning courses used in the banking sector.

\subsection{Presentation of methodology}

As it concerns an exploratory phase of research, we chose a qualitative approach allowing us to better understand the point of view of sales staff on a banking e-learning course. The data was collected using semi-structured individual interviews with sales staff working for branches of various banking networks in France. We then analyzed the words (copied down in writing) of 33 sales advisors. Written dialogue provides an advantage in terms of structure, discipline and homogeneity. The totality of the corpora represents approximately 18 pages in Word format, using single-spaced Times New Roman 12. Taking into account the total volume of the corpus collected, the data was exploited using textual statistics. We used Alceste software which is well adapted to this type of approach. The analysis which follows presents the results of the textual data processing. 


\subsection{Textual statistical analysis}

The analysis of the data collected was carried out using Alceste software ${ }^{3}$. The principle of this method is as follows: the corpus to be analysed is divided into segments of text and one can see the distribution of full words in these segments which gives the method the name: "Analysis of Co-occurent Lexemes in a series of the Text Segments" (Reinert, 1990 and 1998).

Table $n^{\circ}$ 1: English Translation of the segmentation (The original segmentation with French words is in Annexe $n^{\circ} 1$ )

\begin{tabular}{|l|c|l|l|l|l|l|l|l|l|}
\hline \multicolumn{3}{|l|}{ Class 1 (12\% of ECUs) } & \multicolumn{3}{l|l}{ Class 4 (26\% of the ECUs) } & \multicolumn{2}{l|}{ Class 5 (30\% of the ECUs) } \\
\hline $\begin{array}{l}\text { Reduced } \\
\text { forms }\end{array}$ & $\begin{array}{l}\text { e.c.u. } \\
\text { in the } \\
\text { class }\end{array}$ & Khi2 & $\begin{array}{l}\text { Reduced } \\
\text { forms }\end{array}$ & $\begin{array}{l}\text { e.c.u. in } \\
\text { the } \\
\text { class }\end{array}$ & Khi2 & $\begin{array}{l}\text { Reduced } \\
\text { forms }\end{array}$ & $\begin{array}{l}\text { e.c.u. } \\
\text { in the } \\
\text { class }\end{array}$ & Khi2 \\
\hline hourt & 13 & 107.00 & chronometr & 8 & 62.52 & Course & 11 & 97.06 \\
\hline Intranet & 11 & 88.65 & verificat+ion & 6 & 45.96 & End+ & 11 & 97.06 \\
\hline Character + & 10 & 79.76 & service+ & 5 & 37.93 & test+ & 11 & 87.86 \\
\hline Virtu+al & 10 & 79.76 & know+ & 5 & 37.93 & sanction+ & 10 & 87.33 \\
\hline week+ & 10 & 71.25 & employ+e & 6 & 23.66 & success+ & 9 & 77.79 \\
\hline teach+er & 12 & 69.63 & Plan+ & 3 & 22.32 & deliver+ & 9 & 77.79 \\
\hline individual+ & 8 & 62.52 & time & 8 & 21.15 & course & 11 & 54.11 \\
\hline dynam+1 & 8 & 42.15 & course & 7 & 14.50 & Certificate & 5 & 50.32 \\
\hline train+ & 6 & 37.98 & follow & 7 & 13.20 & diploma+ & 6 & 50.32 \\
\hline Post & 10 & 35.47 & access & 7 & 13.20 & advice & 5 & 41.52 \\
\hline
\end{tabular}

The corpus contains 609 distinct forms, 156 reduced forms, 303 hapaxes. The first class (12\% of the EUA) is related to the fourth class and both are related to class 5 according to the factorial analysis.

The first class looks at e-learning courses followed by sales staff (words include Intranet, to teach, virtual - intranet, animer, virtuel). For a standard sentence, we have " $C$ is a training course which lasts one year. The position held in my bank branch is adviser to private customers. At a pace of several hours per month, I am studying an e-learning training course which is taught interactively by virtual characters".

Class 4 deals with the monitoring set up by the HR management to make sure that the sales staff follow the e-learning course regularly (with significant words such as chronometer, checking, knowledge, course - chronomètre, vérification, savoir, parcours). The significant sentences are "each course is timed with a chronometer. Lastly, it is important to note that my company's training department has access to my training programme, and can therefore carry out checks to know if the course has been followed".

Class 5 looks at the point of view of the sales staff concerning the e-learning training which they are following (with the words course, test, diploma, advice - cursus, test, diplome, conseil). An example of a typical sentence would be: "that allows us to provide our customers with good quality advice. Each training course at a professional level is evaluated using tests

\footnotetext{
${ }^{3}$ http://webu2.upmf-grenoble.fr/adest/seminaires/alceste/AlcesteFr.htm
} 
at the end of the course. A certificate is awarded which confirms that the training course has been successfully completed".

Table $n^{\circ}$ 2: English Translation of the segmentation (The original segmentation with French words is in Annexe $n^{\circ}$ )

\begin{tabular}{|l|r|l|l|l|l|}
\hline \multicolumn{3}{|l|}{ Class 6 (12\% of ECUs) } & \multicolumn{3}{l|}{ Class 7 (20\% of the ECUs) } \\
\hline $\begin{array}{l}\text { Reduced } \\
\text { forms }\end{array}$ & $\begin{array}{l}\text { e.c.u.. } \\
\text { in the } \\
\text { class }\end{array}$ & Khi2 & Reduced forms & $\begin{array}{l}\text { e.c.u.. in the } \\
\text { class }\end{array}$ & Khi2 \\
\hline pace+ & 5 & 22.82 & Product+ & 14 & 78.20 \\
\hline Company+ & 7 & 22.57 & Management< & 11 & 75.20 \\
\hline Method+ & 4 & 18.08 & Assets+ & 11 & 75.20 \\
\hline Will+ & 5 & 17.48 & Tax+ & 11 & 75.20 \\
\hline fact & 7 & 16.30 & Sales+ & 11 & 75.20 \\
\hline Work $<$ & 3 & 13.43 & Title+ & 12 & 68.69 \\
\hline Share+ & 3 & 13.43 & bancassurance & 8 & 58.53 \\
\hline Obtain. & 4 & 12.97 & Security+ & 8 & 53.03 \\
\hline Lesson & 7 & 10.39 & Market+ & 8 & 53.03 \\
\hline Salary+ & 8 & 9.44 & Financial+ & 8 & 46.76 \\
\hline Flexible+ & 3 & 8.67 & Internationa+l & 9 & 45.94 \\
\hline
\end{tabular}

Classes 6 and 7 are linked and deal with the organization necessary for the learner to follow the training course, and the content of the banking training course.

Class 6 deals with the organization necessary for the sales staff to be able to follow their elearning training (with the significant words such as pace, method, willingness - rythme, méthode, volonté). The significant sentences are "whether this training works depends on the willingness of those who are following it. It is totally self-paced. For the employer the main benefit lies in the fact that employee stays in the company and does not cause any disruption."

Class 7 deals with the contents of the banking course followed by the sales staff (with the significant words, product, management, assets, bancassurance, international - produit, gestion, patrimoine, bancassurance, international). The significant sentences are "my $e$ learning training is for banking sales advisors. I am taking various courses which were offered to me: taxation of banking products, safety and security, regulation of international financial markets, marketing bancassurance products and asset management".

Our analysis mainly shows that the e-learning debate on training in and improving the use of financial tools focuses on two areas:

- the first relates to the questions of how the course is studied, the subject taught and how satisfied the sales staff are to be following this banking course since it is accessible from the bank branch but also from their home;

- The second highlights the monitoring of the employee by the training department and the HR department within the framework of this training, as well as the level of skills and knowledge that he must acquire. 


\subsection{Discussion}

Generally, e-learning is a vector of change for the sales staff working in the banking networks and for the firm, since it:

- favours the compatibility between the needs of the learner and the training;

- frees itself from time and space constraints, in particular for the sales staff whose superiors require them to remain at their work station certain days of the week, and for those who are required to travel frequently;

- simplifies the logistics (coordination of schedules, transport, accommodation...) and reduces the expenditure incurred with a traditional $\mathrm{F} 2 \mathrm{~F}$ training course;

- offers employees more courses (number and variety) for the same budget as F2F training.

The success of e-learning is also related to the interactivity between man and machine which refers us back to a situation of man-machine dialogue (Linard, 2001). Interactivity is characterized by the activation of any mechanisms which will allow interaction in the interface. Its aim is to provide a space, more often than not virtual, for the exchange of information between the trainer and the trainee. In a learning process, interactivity must primarily guarantee three important points in an e-learning course: the learner's commitment, accessibility to the information and the clarification of this information. It enables sales staff to actively participate remotely in a process of experiential training.

Interactivity also plays a crucial role in the online training courses since it prevents a feeling of isolation and can enable learners to 'get together' without space-time constraints. Interactivity is first and foremost the possibility of instantaneous communication, between two or more people whose reactions depend on the intensity of their learning experience. It also makes it possible to reduce the inhibiting effects of group learning. In some cases, the sales staff can learn more easily when alone in front of the computer than when in a group. It is this solitude which is shown to be a learning accelerator due to the elimination of the negative behaviour which can be observed within a group. The presence of virtual characters (avatars) also contributes to the success of the quality of the e-learning training for the following reasons:

- the use of virtual characters provides situational context, making it possible for the sales advisor to picture each situation;

- the learning aid is animated making it more attractive, and the attention of learner is then rapidly caught by the movements, the sounds of the virtual characters and objects. The learner has the impression that the characters talk to him directly and that he is the sole recipient of the information;

- the animation by virtual characters encourages the sales staff to participate more actively by clicking on them or on objects which surround them;

- The characters, the colours, the surroundings and ergonomics help the sales staff to more easily retain the contents of the training;

E-learning also raises the problem of the learner's commitment and of the effectiveness of the training. In the case of distance learning courses in banking, most are sanctioned by certificates. This facilitates the monitoring of the results by the HR department or the head of training leaving them to concentrate on monitoring the length of time the sales staff are connected. 


\section{Conclusion}

The research that we carried out on sales staff in branch banking in France, led us to conclude that they perceive e-learning as an excellent device to supplement their banking skills. Elearning enables them to acquire new banking skills. For the sales staff in branch banking elearning is very effective since it gives them the possibility to learn in an autonomous way and at their own pace. E-learning ensures the sales staff the flexibility that they are looking for, both to be able to carry out their job as sales advisor and to learn when they want, either in their branch, or at home. They also appreciate the presence of virtual characters who help them to better understand their course.

Corresponding to our expectations, we have noted that the use of e-learning involves a new method of supervision by the banks' HR departments or heads of training: They check the length of time the sales staff are connected and they include it in the organisation of the distance learning courses allowing their sales staff to be just as available for the customers.

Lastly, the results of our research could be prolonged by making a study of the banking institutions in order to draw up a typology of e-learning training strategies. 


\section{Bibliography}

Davis F.D., Bogozzi, R. P., and P. R Marshaw. User acceptance of computer technology: a comparison of two theoretical models // Management Sciences, 1989. - № 35, pp. 982-1003. Dubinsky, A., Howell, R., Ingram T., and D. Bellenger. Sales force socialization // Journal of Marketing, 1986. - № 50, pp. 192-207.

Henning, P.A., A. Schnur. eLearning in continuing medical education: A comparison of knowledge gain and learning efficiency // Journal of Medical Marketing, 2009. - Vol.9, 2, pp. 151-161.

Kalika, M. Le management est mort, vive le e-management // Revue Française de Gestion, 2000. - № 129, pp. 68-79.

Kaplan-Leiserson, E. e-Learning glossary, 2000.

<http://www.learningcircuits.org/glossary.html> Retrieved April 2008.

Keegan, D. Otto Peters on distance education: The industrialization of teaching and learning. London and New York: Routledge, 1994.

Kember, D. The Use of a Model to Derive Interventions Which might Reduce Drop out from Distance Education Courses // Higher Education, 1990. - Vol.20, №1, pp. 11-24.

Linard, M. Concevoir des environnements pour apprendre : l'activité humaine cadre organisateur de l'interactivité technique // Sciences et Techniques Educatives, 2001. - №8, pp. 209-237.

Looney, J. Assessment and Innovation in Education // OECD Education Working Papers 24, OECD, Directorate for Education, 2009.

MSJC Research Office, 2004, Research Report No 04-24, RP.AY04.24, March 11.

Oliver, R.L., E. Anderson. An empirical test of the consequences of behaviour and outcome based sales control systems // Journal of marketing, 1994. - №58, pp. 53-67.

Reinert, M. Une méthode de classification des énoncés d'un corpus présentée à l'aide d'une application // Cahiers Analyse des Données, 1990. - № 1, pp. 21-36.

Reinert, M. Quel objet pour une analyse statistique de discours? Quelques réflexion à propos de la réponse Alceste // In Sylvie Mellet (Eds), JADT, Université de Nice, 1998. - pp. 557569.

Wietz, B., K. Bradford. Personal selling and sales management: a relationship marketing perspective // Journal of the academy of marketing science, 1999. - Vol.27, №2, - pp. 241254.

Zornada, M. E-Learning and the Changing Face of Corporate Training and Development // Managing Global Transitions 3(1), University of Primorska, 2005. - pp. 5-21.

Annexe $n^{\circ} 1$ : The original segmentation with French words of the table $n^{\circ} 1$

\begin{tabular}{|l|l|l|l|l|l|l|l|l|}
\hline \multicolumn{3}{|l|}{ Class 1 $(12 \%$ of ECUs) } & \multicolumn{3}{l|}{ Class 4 (26\% of ECUs) } & \multicolumn{2}{l|}{ Class 5 (30\% of ECUs) } \\
\hline $\begin{array}{l}\text { Reduced } \\
\text { forms }\end{array}$ & $\begin{array}{l}\text { e.c.u. } \\
\text { in the } \\
\text { class }\end{array}$ & Khi2 & $\begin{array}{l}\text { Reduced } \\
\text { forms }\end{array}$ & $\begin{array}{l}\text { e.c.u. in } \\
\text { the } \\
\text { class }\end{array}$ & Khi2 & $\begin{array}{l}\text { Reduced } \\
\text { forms }\end{array}$ & $\begin{array}{l}\text { e.c.u. } \\
\text { in the } \\
\text { class }\end{array}$ & Khi2 \\
\hline heure+ & 13 & 107.00 & chronometr< & 8 & 62.52 & Cursus & 11 & 97.06 \\
\hline Intranet & 11 & 88.65 & verificat+ion & 6 & 45.96 & Fin+ & 11 & 97.06 \\
\hline raison+ & 10 & 79.76 & service+ & 5 & 37.93 & test+ & 11 & 87.86 \\
\hline Personnage & 10 & 79.76 & savoir+ & 5 & 37.93 & $\begin{array}{l}\text { sanctionn+ } \\
\text { er }\end{array}$ & 10 & 87.33 \\
\hline Virtu+el & 10 & 71.25 & employ+e & 6 & 23.66 & reussite+ & 9 & 77.79 \\
\hline semaine+ & 12 & 69.63 & Plan+ & 3 & 22.32 & delivrance+ & 9 & 77.79 \\
\hline
\end{tabular}




\begin{tabular}{|l|c|l|l|r|l|l|r|l|} 
anim+er & 8 & 62.52 & temps & 8 & 21.15 & parcours & 11 & 54.11 \\
\hline particulier+ & 8 & 42.15 & parcours & 7 & 14.50 & Attestation & 5 & 50.32 \\
\hline dynam+1 & 6 & 37.98 & suivre & 7 & 13.20 & diplome+ & 6 & 50.32 \\
\hline forme+ & 10 & 35.47 & acces & 7 & 13.20 & Conseil & 5 & 41.52 \\
\hline Poste & 4 & 22.62 & effectu+er & 7 & 8.53 & client+ & 5 & 41.52 \\
\hline
\end{tabular}

Annexe $n^{\circ} 2:$ The original segmentation with French words of the table $n^{\circ} 2$

\begin{tabular}{|c|c|c|c|c|c|}
\hline \multicolumn{3}{|c|}{ Class $6 \quad(12 \%$ of ECUs) } & \multicolumn{3}{|c|}{ Class 7 ( $20 \%$ of ECUs) } \\
\hline $\begin{array}{l}\text { Reduced } \\
\text { forms }\end{array}$ & $\begin{array}{l}\text { e.c.u. } \\
\text { in the } \\
\text { class }\end{array}$ & Khi2 & Reduced forms & $\begin{array}{l}\text { e.c.u. in the } \\
\text { class }\end{array}$ & Khi2 \\
\hline rythme+ & 5 & 22.82 & Produit+ & 14 & 78.20 \\
\hline Entreprise+ & 7 & 22.57 & Gestion< & 11 & 75.20 \\
\hline Methode+ & 4 & 18.08 & Patrimoine+ & 11 & 75.20 \\
\hline Volonte+ & 5 & 17.48 & Fisca+l & 11 & 75.20 \\
\hline fait & 7 & 16.30 & Commercia+l & 11 & 75.20 \\
\hline Travail< & 3 & 13.43 & Titre+ & 12 & 68.69 \\
\hline Part+ & 3 & 13.43 & bancassurance & 8 & 58.53 \\
\hline obtenir. & 4 & 12.97 & Securite+ & 8 & 53.03 \\
\hline Cours & 7 & 10.39 & Marche+ & 8 & 53.03 \\
\hline Salarie+ & 8 & 9.44 & Financier+ & 8 & 46.76 \\
\hline Souple+ & 3 & 8.67 & Internationa+l & 9 & 45.94 \\
\hline
\end{tabular}

